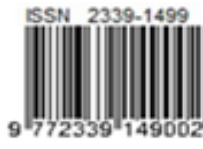

\title{
Peningkatan Produktivitas Leaf Spring Jenis Minicup Tipe MSM 2230 dengan Mengurangi Pemborosan proses Produksi melalui Penerapan Metode Lean Manufacturing
}

\author{
Suparno ${ }^{1}$, Agus Selamet Susanto ${ }^{2}$ \\ 1,2) Fakultas Teknik, Program Studi Teknik Industri Universitas Qomaruddin \\ Jl. Raya Nomor 01 Bungah Gresik, Gresik 61152 \\ Email: suparno@uqgresik.ac.id
}

\begin{abstract}
PT. Indospring is a manufacturing company that produces various springs for an automotive. Among those various springs, MSM 2230 type is the most produced spring at the company. The big problem in producing the spring was related with the high waste that had impact on the low productivity. The purpose of study was to analyze the waste by using the concept of lean manufacturing particularly to identify and eliminate nonvalue added activities. The study found that there were various wastes which waiting and excessive transportation were two dominant wastes with the contribution to total of wastes at $28.96 \%$ and $18.52 \%$ respectively. The appropriate tool for further analysis on wastes was selected by using value stream mapping analysis (VALSAT), and process activity mapping (PAM) was the best tool for analyzing wastes more profoundly. The use of PAM and other tools of fishbone diagram and failure mode effect analysis (FMEA) provided important information for improvement. The implementation of improvement displayed potential increase of productivity level by reducing the processing time of the spring from 113,926.83 minutes to 75,960 minutes.
\end{abstract}

Keywords: lean manufacturing, productivity, value added activities, value stream mapping, waste

\begin{abstract}
Abstrak
PT. Indospring merupakan perusahaan manufaktur yang memproduksi salah satu komponen kendaraan bermotor berupa pegas. Dari berbagai jenis pegas yang diproduksi, pegas dengan tipe MSM 2230 merupakan tipe pegas yang paling dominan diproduksi. Salah satu permasalahan yang dihadapi dalam produksi tipe ini ada tingkat pemborosan yang tinggi. Studi ini bertujuan untuk menganalisis pemborosan dengan menggunakan lean manufacturing yang berfokus pada identifikasi dan eliminasi aktivitas-aktivitas yang tidak memberikan nilai tambah. Dari identifikasi pemborosan diperoleh berbagai macam pemborosan dengan dua di antaranya merupakan pemborosan yang paling dominan yaitu waiting sebesar $28,96 \%$ dan excessive transportation sebesar $18,52 \%$. Analisis lebih detail terhadap pemborosan yang terjadi dibantu dengan tool process activity mapping (PAM) sebagai tool yang terpilih berdasarkan hasil analisis value stream mapping analysis (VALSAT), dikombinasikan dengan fishbone diagram dan failure mode effect analysis (FMEA). Rekomendasi perbaikan memberikan potensi peningkatan produktivitas dengan menurunkan waktu aktivitas proses produksi pegas tipe SM 2230 dari 113.926,83 menit menjadi 75.960 menit.
\end{abstract}

Kata kunci: aktivitas bernilai tambah, lean manufacturing, pemborosan, produktivitas, value stream mapping 


\section{Pendahuluan}

Semua industri manufaktur melakukan proses produksi dengan mengubah bahan baku yang ada di perusahaan menjadi sebuah produk jadi. Produk jadi tersebut diharapkan dapat memenuhi keinginan pelanggan. Setiap tahapan dalam proses produksi menaikkan nilai (added value) dengan cara melakukan perubahan suatu masukan berupa bahan baku, waktu, energi, tenaga kerja menjadi luaran sesuai rencana dengan mengintegrasikan sumber daya yang dimiliki oleh perusahaan. Tanpa koordinasi yang menyeluruh dan sistematis, maka proses produksi akan terhambat, padahal semakin meningkatnya persaingan dalam dunia industri menuntut perusahaan mengelola produksinya menjadi lebih efisien (Jakfar \& Setiawan 2014).

Peningkatan efisiensi dengan mengurangi pemborosan menjadi fokus utama dari PT. Indospring yang merupakan industri manufaktur dalam produksinya memasok komponen kendaraan bermotor berupa pegas. Perusahaan ini sudah menjual hasil produksinya ke Manca Negara. Tentunya kualitas, produktivitas dan ketepatan dalam pengiriman menjadi hal yang sangat penting karena pada saat perakitan mobil ataupun kendaraan lain jika ada salah satu komponen bermasalah akan berpengaruh pada aliran produksi. Kondisi tersebut dapat menghentikan proses produksi atau perakitan yang berujung pada kerugian, karena perusahaan harus mengganti semua kerugian konsumen.

Keterlambatan produksi juga berpengaruh pada akses pengiriman produk jadi ke konsumen. Jika proses produksi sesuai jadwal yang direncanakan, pengiriman produk menggunakan jalur air. Sebaliknya pengiriman akan menggunakan jalur udara jika dalam produksinya ada gangguan. Tentunya perusahaan akan mengeluarkan biaya yang besar. Untuk mengurangi masalah tersebut, perusahaan melakukan perubahan pada proses produksinya dengan cara mengubah metode pada proses produksinya, mengubah mesin agar lebih efektif, memanfaatkan karyawan secara optimal dan memanfaatkan bahan baku serta melakukan efisiensi waktu.

Antar bagian dalam perusahaan memiliki hubungan yang saling terkait satu sama lain, dari bagian desainer, engineering, kualitas, pemasaran, produksi, gudang, dan maintenance. Setiap bagian mempunyai tingkat pemborosan masing-masing. Penelitian ini berfokus pada produksi leaf spring sebagai penyumbang terbanyak pemborosan. Divisi pada produksi leaf spring terdiri atas bagian shearing (pembentukan) dan assembling (perakitan). Alur produksi leaf spring dapat dilihat pada Gambar 1.

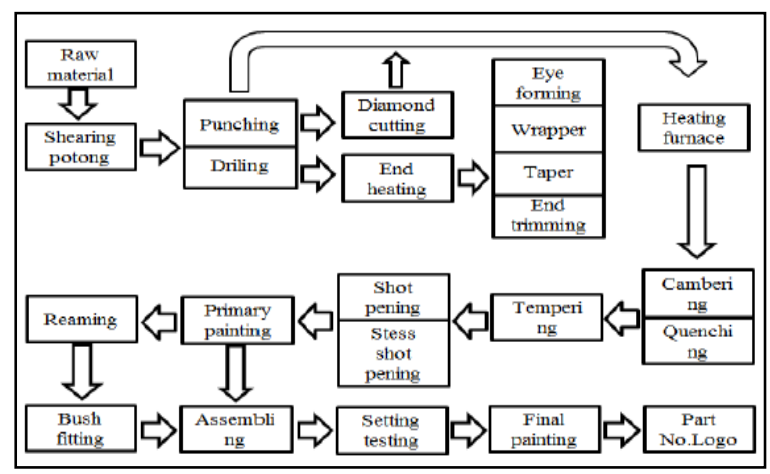

Gambar 1. Alur proses produksi

Berdasarkan studi lapangan selama 3 bulan, mulai bulan Juni 2018 sampai dengan bulan Agustus 2018, produk Minicup merupakan produk dengan jumlah produksi terbanyak sebesar 59.228 set. Sedangkan tipe MSM2230 merupakan tipe dari produk Minicup dengan jumlah produksi terbanyak, yaitu 40.891 set. Tabel 1 menunjukkan jumlah produksi masingmasing tipe Minicup.

Tabel 1. Jumlah produksi tipe Minicup

\begin{tabular}{|c|c|c|c|c|c|}
\hline Jenis & \multirow{2}{*}{ Mminicup } & \multirow{2}{*}{$\%$} & \multicolumn{3}{|c|}{ bulan } \\
\cline { 4 - 6 } & & Juni & Juli & Agustus \\
\hline $\begin{array}{c}\text { MSM } \\
2230\end{array}$ & 40891 & 69,04 & 13545 & 13615 & 13731 \\
\hline $\begin{array}{c}\text { MSM } \\
2075\end{array}$ & 11425 & 19,29 & 3803 & 3807 & 3815 \\
\hline $\begin{array}{c}\text { MSM } \\
2087\end{array}$ & 2680 & 4,53 & 890 & 894 & 896 \\
\hline $\begin{array}{c}\text { MSM } \\
2108\end{array}$ & 2431 & 4,10 & 799 & 812 & 820 \\
\hline $\begin{array}{c}\text { MSM } \\
2138\end{array}$ & 1801 & 3,04 & 586 & 605 & 610 \\
\hline
\end{tabular}

Peningkatan produktivitas produk tipe MSM 2230 perlu dilakukan dengan mengidentifikasi aktivitas-aktivitas apa saja yang dapat meningkatkan nilai tambah serta mengurangi berbagai pemborosan. Pendekatan lean 
manufacturing dapat membantu perusahaan dalam meningkatkan nilai tambah tersebut.

Nilai tambah suatu produk tentunya sangat penting bagi perusahaan karena produk yang dihasilkan mampu bersaing dengan perusahaan sejenis yang lainnya. Melihat begitu pentingnya nilai tambah pada suatu produk, berbagai cara tentunya harus dilakukan perusahaan, diantaranya proses produksi didesain agar menjadi tepat guna dan bernilai guna. Tekniknya dengan menghilangkan pemborosan pada saat proses produksi berlangsung. Jika hal tersebut dilakukan, nilai tambah yang direncanakan akan didapatkan sesuai harapan konsumen dengan sumber daya yang minim pengeluaran biaya (Fernando, 2014).

Langkah perusahaan dalam mengurangi pemborosan dilakukan dengan pendekatan lean manufacturing. Lean manufacturing dibuat dengan mendesain proses produksi yang direncanakan menjadi lebih baik dari sebelumnya, lebih cepat, dan lebih murah dengan biaya inventori yang kecil, biaya pekerja yang murah. Dalam konsep lean manufacturing pemborosan terdiri atas tujuh pemborosan, yaitu produksi yang berlebih, waktu tunggu terlalu lama, transportasi, proses operasi yang terlalu lama, inventori gerakan, dan cacat produk (Fernando, 2014).

\section{Metodologi \\ Produktivitas dan Pemborosan}

Produktivitas ialah rasio antara luaran dengan masukan. Luaran berupa hasil suatu produksi sedangkan masukan berupa semua sumber daya produksi yang ada di perusahaan. Sumber daya tersebut terdiri dari tenaga kerja, energi, modal, peralatan kerja, produksi, mesin, dan waktu. Penerimaan merupakan hasil dari produksi dengan membagi luaran dengan masukan. Untuk meningkatkan penerimaan, maka produktivitas perlu ditingkatkan dengan memanfaatkan sumber daya produksi yang ada di perusahaan secara maksimal (Rejeki et al., 2013). Masukan tersebut dinamakan faktor produksi diantaranya hubungan antar tenaga kerja, tingkat ketrampilan, sikap kerja, manajemen produktivitas, dan kewirausahaan.

Pemborosan tentunya tidak memberikan kontribusi yang positif bagi perusahaan, karena jika dibiarkan terus menerus maka hal ini dapat menghancurkan perusahaan itu sendiri (Nurudin et al., 2015.). Pemborosan dapat didefinisikan sebagai kerugian atau kehilangan dari berbagai sumber daya yang dimiliki oleh perusahaan, yaitu tenaga kerja, mesin, peralatan, waktu, material, dan modal yang diakibatkan oleh kegiatankegiatan di perusahaan karena membutuhkan biaya baik secara langsung maupun tidak langsung, tetapi aktivitas tersebut tidak menambah nilai tambah atas produk akhir yang diproduksi. Pemborosan dalam perusahaan dapat dipandang untuk semua aktivitas yang melibatkan penyerapan sumber daya perusahaan dalam jumlah tertentu tetapi tidak menghasilkan nilai tambah, seperti hasil produksi yang tidak sesuai dengan rencana perusahaan, proses produksi yang mengalami banyak cacat, proses produksi yang tidak perlu, pergerakan tenaga kerja yang tidak memiliki nilai guna, pergerakan dalam kerja yang berlebihan, bahkan sampai produk akhir yang tidak sesuai dengan harapan konsumen.

\section{Lean Manufacturing}

Lean Manufacturing merupakan suatu pendekatan sistematis yang dapat dilakukan perusahaan untuk identifikasi jenis pemborosan yang terjadi selama proses produksi dan upaya yang harus dilakukan perusahaan untuk dapat mengurangi pemborosan dari setiap kegiatan dalam perusahaan dengan tidak memberi nilai manfaat (non value added activities) melalui upaya perbaikan yang dilakukan secara berkelanjutan dengan tujuan kepuasan pelanggan (Khannan \& Haryono, 2017). Pemborosan tersebut dianalisis oleh seorang Taichi Ohno yang berkerja sebagai eksekutif Toyota. Taichi Ohno merupakan orang pertama yang mencetuskan bahwa pemborosan yang terjadi di perusahaan itu ada tujuh macam (Gaiardelli, 2018).

Lean Manufacturing merupakan filosofi manufaktur yang memperpendek waktu antara pesanan pelanggan dan pengiriman barang dengan menghilangkan sumber pemborosan (Bhasin, 2013). Dengan menghilangkan pemborosan, maka waktu proses akan semakin pendek. Tujuan utamanya adalah melakukan identifikasi dan eliminasi segala aktivitas di 
perusahaan yang tidak memberikan nilai tambah baik dalam perencanaan, desain produksi atau operasional dan juga untuk manajemen rantai pasok yang berhubungan langsung dengan pelanggan.

Fleksibilitas pada sistem produksi di perusahaan melalui konsep lean manufacturing akan mampu beradaptasi secara cepat dan tepat terhadap setiap perubahan terhadap kebutuhan pelanggan dengan sistem produksi yang lebih ramping sehingga persediaan perusahaan menjadi minim (Hazmi \& Hakim, 2012). Tidak hanya rendahnya persediaan yang harus disediakan oleh perusahaan, pendekatan menggunakan konsep ini dapat mengurangi persediaan pada perusahaan yang tidak diperlukan, proses produksi lebih efisien, tentunya akan terjadi penghematan biaya, dan cacat produk dapat dikurangi, begitu juga waktu tunggu produksi (Hazmi \& Hakim, 2012).

Konsep lean manufacturing merupakan suatu konsep perbaikan untuk mengurangi pemborosan yang pada mulanya dikembangkan oleh Toyota. Kemudian dikenal sebagai Just-In-Time Manufacturing (Ristyowati \& Muhsin, 2017). Konsep lean manufacturing ini memiliki tujuan untuk melakukan perubahan pada suatu organisasi di perusahaan untuk menjadi lebih efisien, efektif dan juga memiliki kemampuan untuk bersaing. Untuk melakukan perubahan pada suatu organisasi, konsep lean manufacturing diaplikasikan untuk mengurangi lead time dan mampu meningkatkan output suatu produksi dengan menghilangkan pemborosan yang terjadi selama produksi tersebut (Ristyowati \& Muhsin, 2017).

Pemborosan terbagi ke dalam tujuh tipe sebagai berikut (Adrianto \& Kholil, 2016):

1. Menunggu

Ketika ada material tidak bergerak atau diproses akan mengakibatkan lead time dari satu tahap ke tahap produksi berikutnya. Lead time ini ketika pergerakan material dari satu tahap ke tahap produksi berikutnya berjalan sangat buruk, sehingga aliran material dalam produksi terlalu lama sehingga jarak antara work center menjadi sangat besar.

\section{Transportasi}

Transportasi merupakan kegiatan memindahkan bahan atau material dari satu tempat ke tempat berikutnya. Proses ini akan menimbulkan biaya tambahan dan tidak berdampak pada konsumen, malah risiko kerusakan material lebih besar.

3. Produksi berlebihan

Terjadi ketika perusahaan membuat suatu produk dengan batch cukup besar dalam waktu yang lama. Produksi yang berlebih ini akan menjadi masalah bagi biaya penyimpanan di gudang.

4. Gerakan kerja

Gerakan operator atau fasilitas produksi seperti mesin yang ada di perusahaan yang tidak seharusnya. Pergerakan ini akan mengakibatkan stress pada operator.

5. Proses yang berlebihan

Operator bekerja dengan teknik atau cara yang tidak standar, peralatan yang digunakan tidak sebagaimana mestinya, atau toleransi yang dibuat tanpa melalui perhitungan dan analisis terlebih dahulu.

6. Persediaan

Bagian dari semua produk berupa bahan baku, barang setengah jadi ataupun barang jadi yang belum dijual menjadi biaya tambahan yang harus ditanggung perusahaan.

7. Cacat

Barang yang rusak memerlukan penanganan lebih, apakah dilakukan pengerjaan ulang, ataupun perbaikan yang akan menambah biaya produksi.

\section{Value Stream Mapping}

Value stream mapping adalah perangkat dari manajemen kualitas yang digunakan oleh perusahaan untuk melakukan perbaikan dan mengurangi pemborosan, juga untuk memetakan sebuah jalur produksi suatu produk masingmasing stasiun kerja (Adrianto \& Kholil, 2016). Penggambaran value stream mapping dimulai dengan gambaran besar dalam menyelesaikan permasalahan (Adrianto \& Kholil, 2016). Metode Value Stream Mapping merupakan suatu metode yang mampu memberi gambaran secara visualisasi secara efisien keadaan suatu sistem yang ada di perusahaan saat ini, dan kemampuannya dalam mengidentifikasi visi jangka panjang perusahaan menjadi suatu 
rencana untuk mendapatkan tujuan yang diinginkan.

Metode Value Stream Mapping digunakan untuk membantu dalam mengidentifikasi pemborosan. Apabila pemborosan ditemukan maka pemborosan tersebut harus dieliminasi. Tujuan dari VSM adalah untuk process improvement dalam sebuah sistem (Prayogo \& Octavia, 2013).

\section{VALSAT (Value Stream Mapping Analysis Tool)}

Value stream analysis tool (VALSAT) merupakan suatu perangkat yang digunakan untuk melakukan mapping secara detail berdasarkan jenis pemborosan yang telah ditemukan pada perusahaan. Jenis pemborosan tersebut dipetakan secara detail aliran nilainya yang difokuskan pada value adding activity, sehingga akar penyebab terjadinya pemborosan dapat diklasifikasikan. Terdapat tujuh macam detail mapping tool, diantaranya: (1) process activity mapping, (2) supply chain matrix, (3) production variety funnel, (4) quality filter mapping, (5) demand amplification mapping, (6) decision point analysis, dan (7) physical structure.

VALSAT juga dapat digunakan untuk memetakan pelaksanaan proyek mulai dari perencanaan dari pengadaan barang hingga siap dikirim untuk memenuhi pemesan konsumen. Tujuan lainnya untuk mengevaluasi tipe job order yang ada dalam proses produksi dan menganalisis jenis pemborosan yang memiliki potensi paling banyak terjadi serta kemampuan untuk memberikan rekomendasi perbaikan.

Value stream mapping yang dipilih adalah hasil VALSAT yang menunjukkan skor total terbesar akan dijadikan mapping terpilih untuk dapat mengidentifikasi pemborosan secara detail. Pemilihan yang dilakukan ini didasarkan bahwa value stream mapping yang terpilih dengan nilai terbesar tersebut paling sesuai untuk mengidentifikasi pemborosan pada value stream.

\section{FMEA (Failure Mode and Effect Analysis)}

Metode FMEA dikembangkan sekitar tahun 1960-an, ketika gerakan mutu mulai timbul. Pemakaian secara formal dimulai di industri dirgantara sekitar tahun itu, di mana kepedulian terhadap keselamatan penerbangan sangat tinggi
(Adrianto \& Kholil, 2016). Menggunakan FMEA tidak dapat dipisahkan dari penggunaan Risk Priority Number (RPN) yang merupakan hasil perkalian dari pembobotan atau pemberian rating terhadap suatu mode kegagalan (Adrianto \& Kholil, 2016). RPN diperoleh dengan menggunakan formula sebagai berikut.

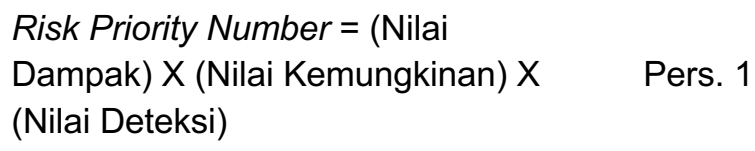

Total nilai RPN ini dihitung untuk tiap-tiap kesalahan yang mungkin terjadi. Bila proses tersebut terdiri dari kelompok-kelompok tertentu maka jumlah keseluruhan RPN pada kelompok tersebut dapat menunjukkan tingkat kegawatan kelompok proses tersebut bila suatu kesalahan terjadi (Adrianto \& Kholil, 2016).

FMEA adalah sebuah metode evaluasi kemungkinan terjadinya sebuah kegagalan dari sebuah sistem, desain, proses atau servis untuk selanjutnya dibuat langkah penanganannya. Dalam FMEA setiap kemungkinan kegagalan yang terjadi dikuantifikasi untuk dibuat prioritas penanganannya.

\section{Hasil dan Diskusi}

\section{Pengumpulan Data}

Bahan baku pembuatan leaf spring jenis minicup tipe MSM 2230 adalah baja pegas yang berstandar JIS (Japanese Industrial standards). Baja pegas yang digunakan adalah jenis SUP 9, komposisi kimia dari baja pegas SUP 9 adalah sebagai berikut:

$$
\begin{aligned}
& \text { C : } 0,52-0,60 \% \\
& \text { Si }: 0.15-0,35 \% \\
& \text { Mn: } 0,65-0.95 \% \\
& \text { Cr : } 0,65-0,95 \%
\end{aligned}
$$

Data kebutuhan material untuk produksi sesuai Tabel 2 berikut.

Tabel 2. Kebutuhan material produksi

\begin{tabular}{|c|l|c|}
\hline No. & Bulan & Jumlah (Ton) \\
\hline 1 & Juni & 162 \\
\hline 2 & Juli & 163 \\
\hline 3 & Agustus & 164 \\
\hline 4 & September & 163 \\
\hline 5 & Oktober & 164 \\
\hline 6 & November & 164 \\
\hline
\end{tabular}


Data kebutuhan waktu untuk tiap mesin dapat dilihat pada Tabel 3 berikut ini.

Tabel 3. Kebutuhan waktu siklus untuk tiap mesin

\begin{tabular}{|c|l|c|}
\hline No. & \multicolumn{1}{|c|}{ Nama Mesin } & Cycle Time (detik) \\
\hline 1 & Cutting & 7 \\
\hline 2 & Center hole & 7 \\
\hline 3 & Drilling $(\mathrm{CH})$ & 40 \\
\hline 4 & Silencer hole & 7 \\
\hline 5 & Rivet hole & 9 \\
\hline 6 & Bevel & 7 \\
\hline 7 & Corner press & 20 \\
\hline 8 & Eye forming & 20 \\
\hline 9 & Taper & 12 \\
\hline 10 & Press quenching & 12 \\
\hline 11 & Press roll & 10 \\
\hline 12 & Shot peening & 7 \\
\hline 13 & Cat dasar & 30 \\
\hline 14 & Reamer & 30 \\
\hline 15 & Bushing & 20 \\
\hline 16 & Riveting klip & 30 \\
\hline 17 & Perakitan & 30 \\
\hline 18 & Setiing Load & 35 \\
\hline 19 & Cat finish & 5 \\
\hline 20 & Part number & \\
\hline
\end{tabular}

Pada bagian gudang produk jadi, data yang diperlukan untuk penelitian adalah data penyimpanan tiap bulan dan data yang dikirim ke konsumen tiap bulan. Tabel 4 dan 5 berikut adalah data-data yang diperlukan.

Tabel 4. Penyimpanan produk di gudang produk jadi

\begin{tabular}{|c|l|c|}
\hline No. & \multicolumn{1}{|c|}{ Bulan } & Jumlah (Set) \\
\hline 1 & Juni & 13.545 \\
\hline 2 & Juli & 13.615 \\
\hline 3 & Agustus & 13.731 \\
\hline 4 & September & 13.667 \\
\hline 5 & Oktober & 13.752 \\
\hline 6 & November & 13.822 \\
\hline
\end{tabular}

Tabel 5. Pengiriman produk jadi ke konsumen

\begin{tabular}{|c|l|c|}
\hline No. & \multicolumn{1}{|c|}{ Bulan } & Jumlah (Set) \\
\hline 1 & Juni & 11.545 \\
\hline 2 & Juli & 12.615 \\
\hline 3 & Agustus & 11.631 \\
\hline 4 & September & 12.343 \\
\hline 5 & Oktober & 12.455 \\
\hline 6 & November & 12.543 \\
\hline
\end{tabular}

\section{Identifikasi dan Pembobotan Pemborosan}

Penyebaran kuesioner 7 pemborosan ini digunakan untuk mengetahui pemborosan apa saja yang terjadi di perusahaan. Kemudian dilakukan pembobotan dari hasil penyebaran kuesioner 7 pemborosan untuk menentukan pemborosan apa saja yang dominan di dalam perusahaan. Setelah diketahui pemborosanpemborosan yang terjadi di perusahaan berdasarkan tingkat pembobotan yang paling tinggi, kemudian dilakukan pemilihan tool untuk mengurangi pemborosan. Dari perhitungan bobot masing-masing pemborosan tersebut, diketahui bahwa pemborosan terbesar yang terjadi di perusahaan adalah waiting, excessive transportation, over production, unnecessary inventory, defect, unnecessary motion, dan inappropriate processing seperti yang terlihat pada Tabel 6.

Tabel 6. bobot dan rangking waste

\begin{tabular}{|c|l|c|}
\hline Rangking & \multicolumn{1}{|c|}{ Waste } & Bobot \\
\hline $\mathbf{1}$ & Waiting & $28,96 \%$ \\
\hline $\mathbf{2}$ & Excessive transportation & $18,52 \%$ \\
\hline $\mathbf{3}$ & Over production & $16,83 \%$ \\
\hline $\mathbf{4}$ & Unnecessary inventory & $15,49 \%$ \\
\hline $\mathbf{5}$ & Defect & $13,47 \%$ \\
\hline $\mathbf{6}$ & Unnecessary motion & $4,04 \%$ \\
\hline $\mathbf{7}$ & Inappropriate processing & $2,69 \%$ \\
\hline \multicolumn{2}{|c|}{ Total } & $100 \%$ \\
\hline
\end{tabular}

\section{Pemilihan Mapping Tool}

Dalam VALSAT ini terdapat tujuh tool yang digunakan untuk menganalisis pemborosan. Value stream mapping dengan total skor terbesar menurut hasil VALSAT akan dijadikan mapping terpilih untuk mengidentifikasi pemborosan secara detail. Pemilihan ini didasarkan bahwa value stream mapping dengan nilai terbesar tersebut paling sesuai untuk mengidentifikasi pemborosan pada value stream, seperti yang terlihat pada Tabel 7 .

\section{Process Activity Mapping}

Mapping ini adalah pendekatan teknis yang dapat dipergunakan pada aktivitas-aktivitas yang terjadi di lantai produksi. Dasar dari konsep ini adalah memetakan setiap tahap aktivitas yang terjadi mulai dari transportasi, inspeksi, operasi, storage, dan delay. Langkah berikutnya adalah mengelompokkan ke dalam tipe-tipe aktivitas yang ada mulai dari necessary non value adding activities, value adding activities, dan non value adding activities. Tujuan dari pendekatan ini adalah untuk melakukan eliminasi dari aktivitas yang dianggap tidak bermanfaat, menyederhanakan, mengombinasikan, serta 
DOI: https://doi.org/10.26593/jrsi.v10i1.3813.89-100

Tabel 7. Pemilihan tool dengan menggunakan VALSAT

\begin{tabular}{|c|c|c|c|c|c|c|c|}
\hline $\begin{array}{l}\text { Waste/ } \\
\text { structure }\end{array}$ & $\begin{array}{l}\text { Process } \\
\text { activity } \\
\text { mapping }\end{array}$ & $\begin{array}{l}\text { Supply chain } \\
\text { response } \\
\text { matrix }\end{array}$ & $\begin{array}{c}\text { Production } \\
\text { variety } \\
\text { Funnel }\end{array}$ & $\begin{array}{c}\text { Quality } \\
\text { filter } \\
\text { mapping }\end{array}$ & $\begin{array}{c}\text { Demand } \\
\text { amplification } \\
\text { mapping }\end{array}$ & $\begin{array}{c}\text { Decisionpoint } \\
\text { Analysis }\end{array}$ & $\begin{array}{l}\text { Phisical } \\
\text { structure }\end{array}$ \\
\hline Over production & 16,83 & 50,49 & & 16,83 & 50,49 & 50,49 & \\
\hline Waiting & 260,64 & 260,64 & 28,96 & & 86,88 & 86,88 & \\
\hline Transportation & 166,68 & & & & & & 18,52 \\
\hline $\begin{array}{l}\text { Unappropriated } \\
\text { processing }\end{array}$ & 24,21 & & 8,07 & 2,69 & & 2,69 & \\
\hline $\begin{array}{l}\text { Unnecessary } \\
\text { inventory }\end{array}$ & 46,47 & 139,41 & 46,47 & & 139,41 & 46,47 & 15,49 \\
\hline $\begin{array}{l}\text { Unnecessary } \\
\text { motion }\end{array}$ & 36,36 & 4,04 & & 36,36 & & & \\
\hline Defects & 13,47 & & & & & & \\
\hline Total & 564,66 & 454,58 & 83,5 & 55,88 & 276,78 & 186,53 & 34,01 \\
\hline
\end{tabular}

mengubah setiap rangkaian yang akan mengurangi pemborosan.

Berdasarkan data dari process activity mapping, tabel kegiatan tipe aktivitas dan waktu yang dibutuhkan disusun seperti yang terlihat pada Tabel 8. Berdasarkan Tabel 8 dapat diketahui bahwa proses leaf spring jenis minicup tipe MSM 2230 memiliki NNVA (necessary nonvalue added activity) waktu paling banyak yaitu $113.551,43$ menit dan persentase $99,67 \%$ dari konsumsi waktu keseluruhan proses.

Dari hasil di atas dapat diidentifikasikan beberapa hal yang terjadi dalam proses produksi sebagai berikut:

1. Operasi

Proses produksi melibatkan 85 aktivitas dan terdapat 30 aktivitas yang termasuk dalam kategori value adding activity atau sekitar $35,29 \%$ dari semua tipe aktivitas. Waktu yang dibutuhkan dalam melakukan aktivitas yang bernilai tambah adalah 6.324 detik atau sekitar 105,4 menit atau sekitar $0,09 \%$ dari semua tipe aktivitas.

2. Transportasi

Terdapat 35 kali transportasi. Waktu yang dibutuhkan adalah 9.086 detik atau sekitar
151,43 menit atau sekitar $0,133 \%$ dari semua tipe aktivitas.

3. Inspeksi

Inspeksi dilakukan sebanyak 7 kali. Total waktu yang dibutuhkan untuk melakukan inspeksi adalah 275 detik atau sekitar 4,58 menit atau sekitar $0,004 \%$ dari semua tipe aktivitas.

4. Storage

Sebagian besar waktu penyimpanan digunakan untuk aktivitas penyimpanan bahan baku dengan waktu penyimpanan sekitar 60 hari dan untuk produk jadi disimpan di gudang produk jadi dalam waktu 30 hari.

5. Delay

Terdapat 18 kali aktivitas delay. Total waktu yang dibutuhkan adalah 16.200 detik atau sekitar 270 menit atau sekitar 0,237\% dari semua tipe aktivitas.

\section{Fishbone Diagram}

Hasil analisa fishbone diagram dari setiap cacat produk pada proses taper tipe MSM 2230 dapat dilihat pada Gambar 2 - 5.

Tabel 8. Jumlah kegiatan tipe aktivitas proses produksi

\begin{tabular}{|l|c|c|c|c|c|c|}
\hline & Operasi & Transportasi & Inspeksi & Storage & Delay & Jumlah \\
\hline Jumlah kegiatan & 23 & 35 & 7 & 2 & 18 & 85 \\
\hline Persentase kegiatan & 27,06 & 41,18 & 8,23 & 2,35 & 21,18 & 100 \\
\hline Waktu (menit) & 100,82 & 151,43 & 4,58 & 113.400 & 270 & 113926,83 \\
\hline Persentase waktu & 0,088 & 0,133 & 0,004 & 99,538 & 0,237 & 100 \\
\hline
\end{tabular}




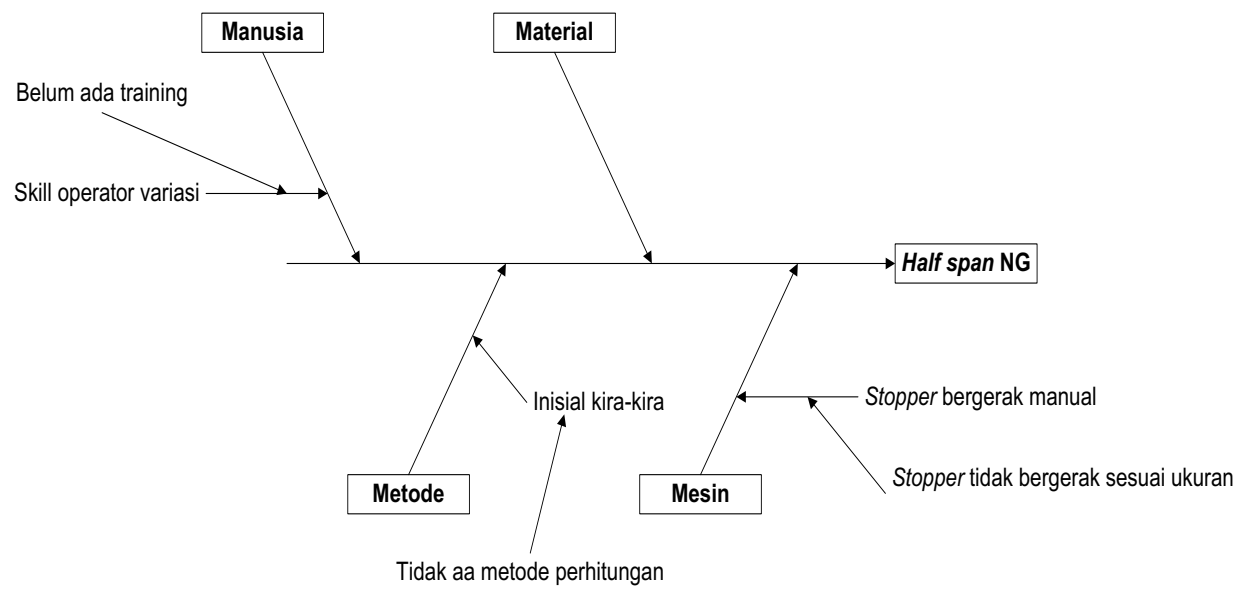

Gambar 2. Fishbone diagram cacat half span NG

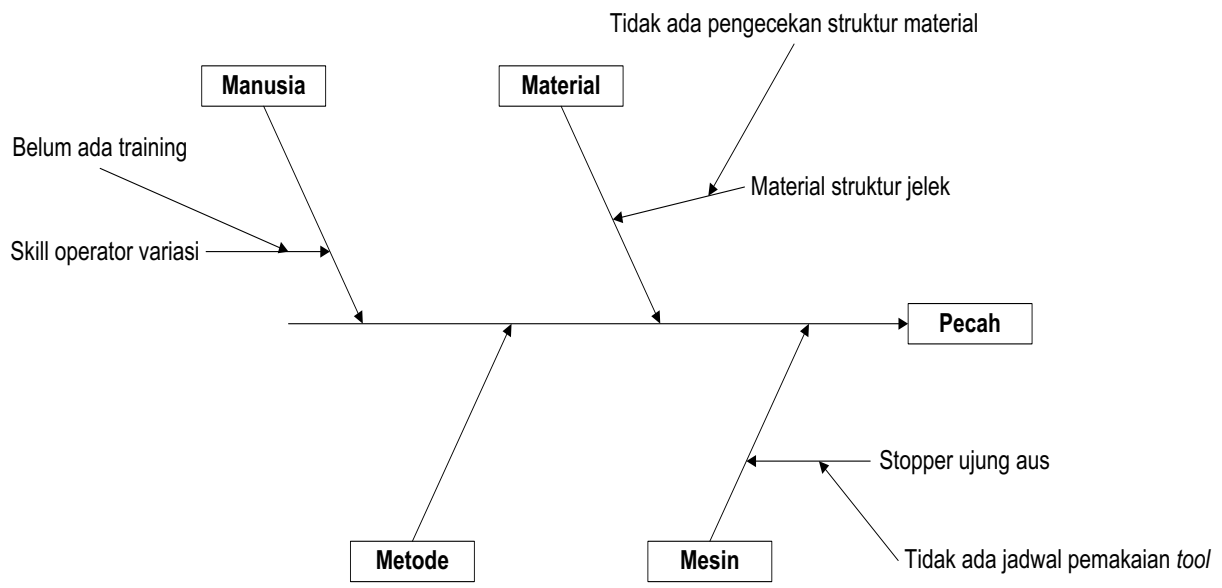

Gambar 3. Fishbone diagram cacat pecah

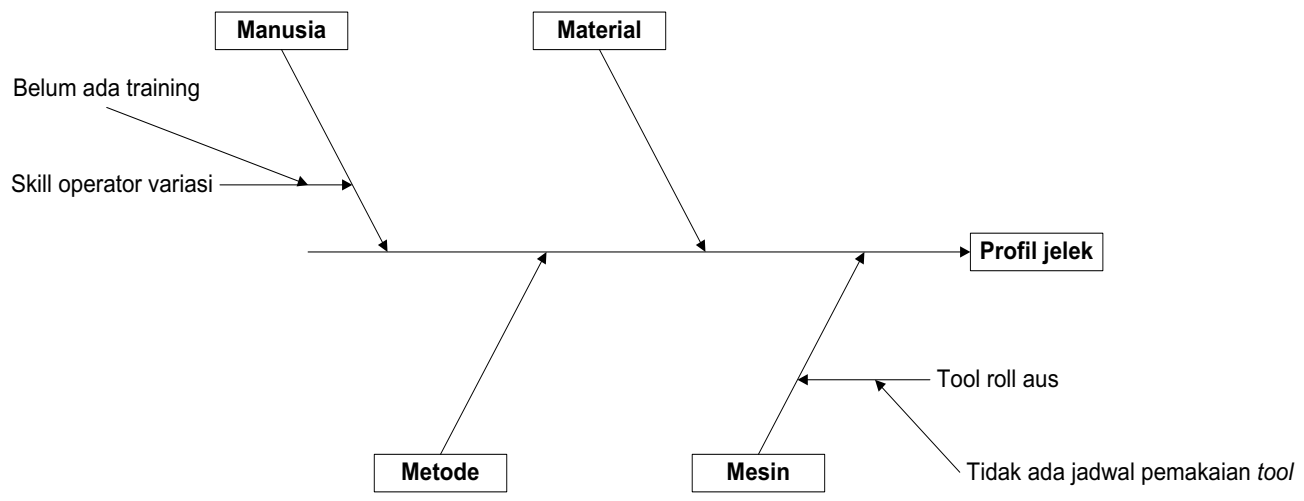

Gambar 4. Fishbone diagram cacat bow 


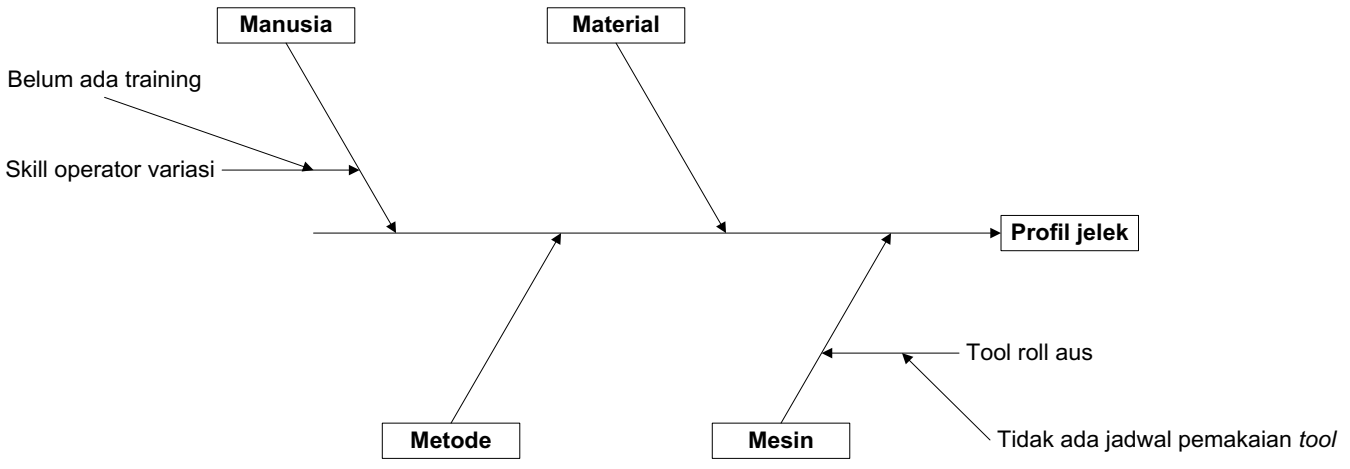

Gambar 5. Fishbone diagram cacat profil jelek

\section{Rekomendasi Perbaikan Berdasarkan FMEA}

Akar masalah yang diidentifikasi pada fishbone diagram dianalisis dengan menggunakan metode FMEA untuk mengetahui tingkat kritis dari penyebab terjadinya pemborosan. Tingkat kekritisan ini ditunjukkan dalam bentuk perhitungan Risk Priority Number (RPN). Untuk melakukan analisis dengan menggunakan FMEA, RPN ditentukan dengan menggunakan perkalian antara rating dari Severity, Occurrence, dan Detection yang hasilnya dinyatakan dalam bentuk angka. Tabel 9 menunjukkan hasil analisis FMEA.

Berdasarkan hasil analisis FMEA, rekomendasi perbaikan diusulkan sebagai berikut:

a. Flat bar harus ada di gudang sekitar 2 bulan sebelum proses produksi dimulai, dan diperpendek menjadi 1 bulan sehingga waiting time pada alur proses bisa berkurang.

b. Proses pendinginan pada proses eye forming setelah proses eye forming sisi $\mathrm{A}$ bisa mengakibatkan delay dan waiting pada proses punching. Oleh karena itu setelah proses eye forming sisi A bisa langsung melakukan proses punching dengan mengubah metode perhitungan dan layout perusahaan, dengan mendekatkan mesin eye forming dengan mesin center hole.

c. Pada proses taper sisi A ada proses pendinginan setelahnya, dan dibuatkan penjepit taper sehingga proses taper bisa dilakukan secara langsung dari sisi A ke sisi B tanpa adanya delay berupa proses pendinginan.

d. Pada pengeringan cat dasar ada delay di atas conveyor. Pemasangan hot blower dapat mempercepat proses pendinginan pada cat dasar.

\section{Penggambaran Future State Map}

Setelah melakukan analisa dan memberikan rekomendasi perbaikan, langkah selanjutnya penggambaran Future State Map. Value stream sistem produksi dengan memvisualisasikan aliran fisik dan aliran informasi dari sistem produksi perusahaan seperti yang terlihat pada Gambar 6 dan 7 .

Tabel 9. FMEA leaf spring tipe MSM 2230

\begin{tabular}{|c|c|c|c|c|c|c|c|c|}
\hline No. & $\begin{array}{c}\text { Failure } \\
\text { Mode }\end{array}$ & $\begin{array}{c}\text { Failure } \\
\text { effect }\end{array}$ & Sev. & \multicolumn{1}{|c|}{ Causes } & Occ. & \multicolumn{1}{c|}{ Control } & Det. & RPN \\
1. & Half span NG & Reproses & 4 & $\begin{array}{l}\text { 1. Stopper Manual } \\
\text { 2. Inisial kira-kira }\end{array}$ & 4 & $\begin{array}{l}\text { 1. Mengganti auto } \\
\text { stopper } \\
\text { 2. Metode } \\
\text { perhitungan }\end{array}$ & 3 \\
\hline 2. & Profil jelek & Disorter & 1 & Tool roll aus & 2 & Mengganti roll & 2 & 4 \\
\hline 3. & Pecah & Reproses & 3 & $\begin{array}{l}\text { 1. Stopper ujung } \\
\text { aus } \\
\text { 2. Struktur jelek }\end{array}$ & 2 & $\begin{array}{l}\text { 1. Mengganti stopper } \\
\text { 2. Metode } \\
\text { pengecekan }\end{array}$ & 2 & 12 \\
\hline 4. & Bow & Disorter & 2 & $\begin{array}{l}\text { Stopper samping } \\
\text { aus }\end{array}$ & 1 & Mengganti stopper & 2 & 4 \\
\hline
\end{tabular}




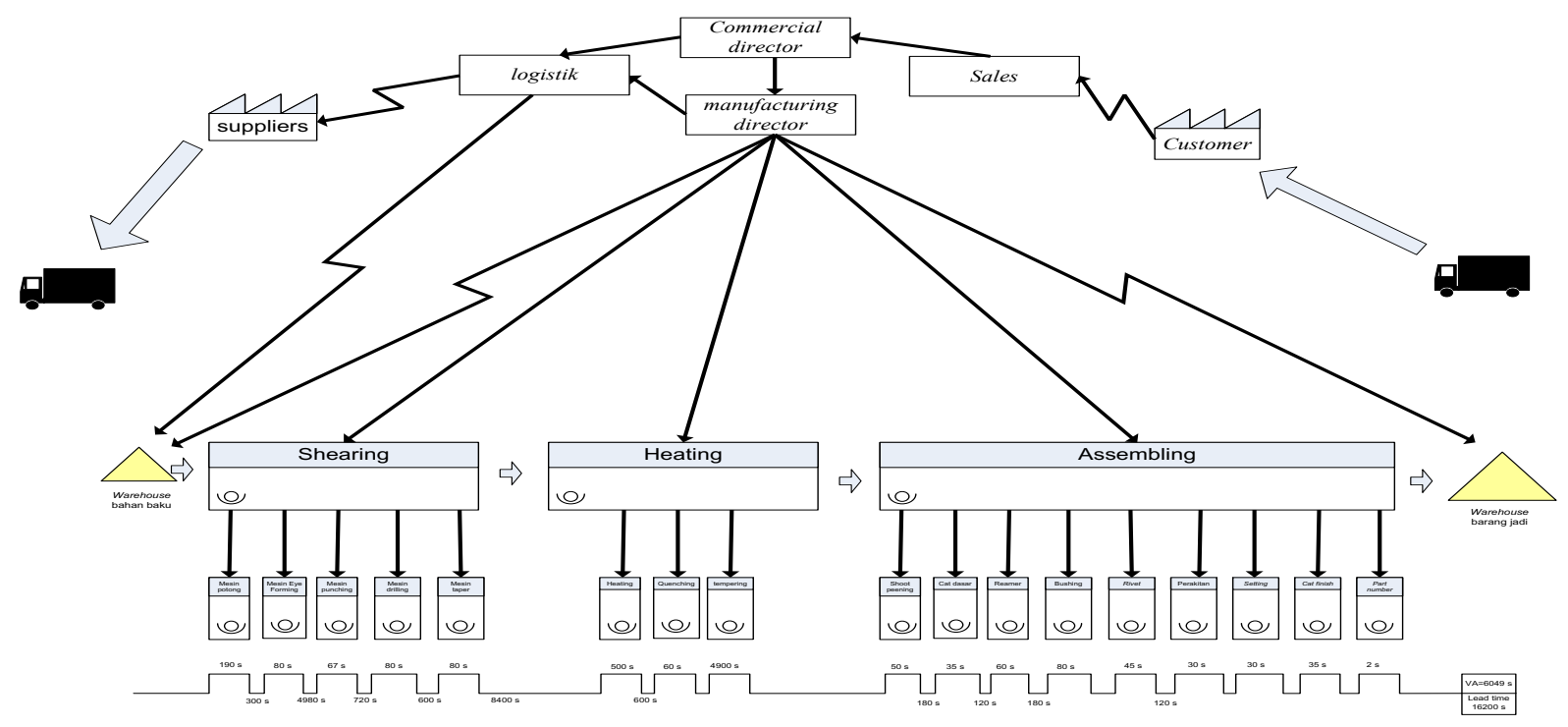

Gambar 6. Value stream mapping saat ini

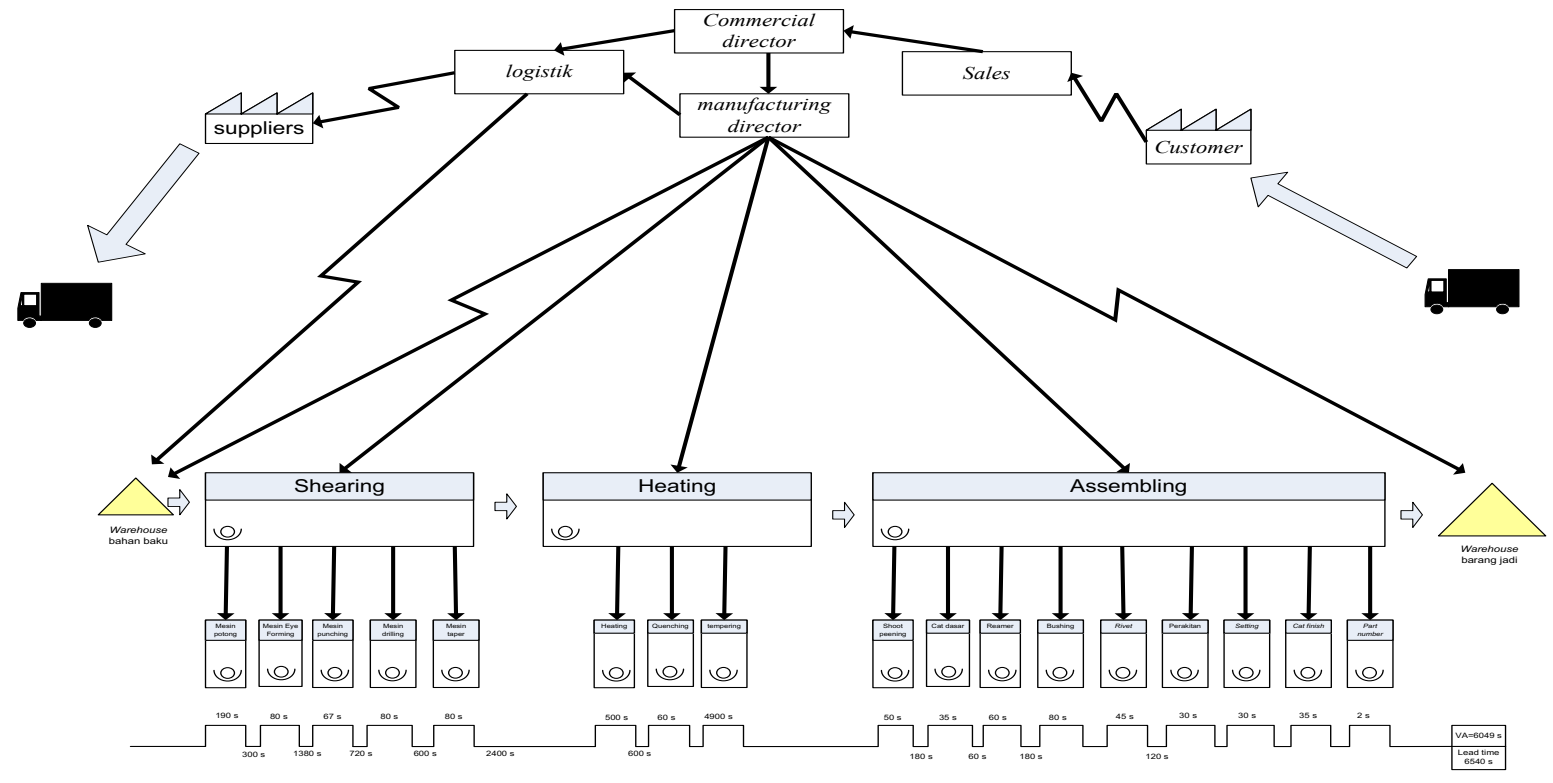

Gambar 7. Value stream mapping usulan

Pada proses activity mapping Diketahui waktu untuk tiap tipe aktivitas adalah sebagai berikut:

a. Operasi $=6.049$ detik $=100,82$ menit

b. Transportasi $=8.736$ detik $=145,6$ menit

c. Inspeksi $=275$ detik $=4,58$ menit

d. Storage $=453600$ detik $=75600$ menit

e. Delay $=6540$ detik $=109$ menit

Total waktu $=4557600$ detik $=75960$ menit

Berdasarkan kebutuhan waktu untuk tiap tipe aktivitas, waktu yang dibutuhkan untuk aktivitas pada value stream mapping usulan dapat dilihat pada Tabel 10.

Tabel 10. Waktu tiap aktivitas usulan

\begin{tabular}{|c|c|c|c|c|c|c|}
\hline & \multicolumn{5}{|c|}{ Aktivitas } & \multirow[b]{2}{*}{$\begin{array}{l}\frac{\frac{\sigma}{\pi}}{\frac{\pi}{\xi}} \\
\frac{j}{7}\end{array}$} \\
\hline & $\begin{array}{l}\bar{g} \\
\bar{\sigma} \\
\overline{0} \\
\text { ö }\end{array}$ & 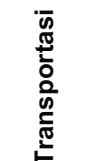 & $\begin{array}{l}\bar{w} \\
\underline{\omega} \\
\bar{o} \\
\underline{\omega}\end{array}$ & 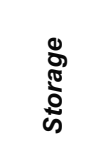 & $\frac{\vec{\Phi}}{\square}$ & \\
\hline $\begin{array}{l}\text { Waktu } \\
\text { (menit) }\end{array}$ & 100,82 & 145,6 & 4,58 & 75600 & 109 & 75960 \\
\hline Persentase & 0,133 & 0,192 & 0,006 & 99,526 & 0,143 & 100 \\
\hline
\end{tabular}


Persentase aktivitas value added (VA), necessary non value added (NNVA), dan non value added (NVA) dapat dilihat pada Tabel 11.

Tabel 11. Waktu tiap jenis aktivitas

\begin{tabular}{|l|c|c|c|}
\hline Aktivitas & Jumlah & $\begin{array}{c}\text { Waktu } \\
\text { (menit) }\end{array}$ & Persentase \\
\hline VA & 30 & 105,4 & 0,14 \\
\hline NNVA & 34 & 75745,6 & 99,72 \\
\hline NVA & 15 & 109 & 0,14 \\
\hline TOTAL & 79 & 75960 & 100 \\
\hline
\end{tabular}

\section{Kesimpulan}

a. Dari hasil pembobotan, dapat diketahui bobot dan jenis pemborosan yang berpengaruh signifikan sepanjang value stream pada sistem produksi adalah sebagai berikut :

1) Waiting: $28,96 \%$

2) Excessive transportation: $18,52 \%$

b. Usulan perbaikan untuk mengurangi pemborosan antara lain pembuatan stopper otomatis, pembuatan jadwal pemakaian tool, pembuatan metode pemeriksaan bow.

c. Dari hasil analisa Process Activity Mapping (PAM) didapatkan bahwa terdapat 23 kegiatan operasi, 35 kegiatan transportasi, 7 kegiatan inspeksi, 2 kegiatan storage, 18 kegiatan delay dengan waktu $113.926,83$ menit pada sistem saat ini; dan 23 kegiatan operasi, 32 kegiatan transportasi, 7 kegiatan inspeksi, 2 kegiatan storage, 15 kegiatan delay dengan waktu 75960 menit pada sistem usulan. Oleh karena itu terdapat peningkatan produktivitas tipe MSM 2230.

\section{Daftar Pustaka}

Adrianto, W., \& Kholil, M. (2016). Analisis Penerapan Lean Production Process untuk Mengurangi Lead Time Proses Perawatan Engine (Studi Kasus PT.GMF AEROASIA). Jurnal Optimasi Sistem Industri, 14(2), 299309.

Bhasin, S. (2013). Lean Management Beyond Manufacturing. Cham: Springer International Publishing.
Fernando, Y. C. (2014). Optimasi Lini Produksi dengan Value Stream Mapping dan Value Stream Analysis Tools, Jurnal IImiah Tekni Industri, 13(2), 125-133.

Gaiardelli, P. (2018). Faster, Better, Cheaper' in the History of Manufacturing: From the Stone Age to Lean Manufacturing and Beyond. Production Planning and Control, 29(2), 184184.

Hazmi, F. W., \& Hakim, J. A. R. (2012). Penerapan Lean Manufacturing untuk Mereduksi Waste di PT. ARISU. Jurnal Teknik ITS, 1(1), 135-140.

Jakfar, A. \& Setiawan, W. E. (2014). Pengurangan Waste Menggunakan Pendekatan Lean Manufacturing. Jurnal IImiah Tekni Industri, 13(1), 43-53.

Khannan, M. S. A., \& Haryono, H. (2017). Analisis Penerapan Lean Manufacturing untuk Menghilangkan Pemborosan di Lini Produksi PT. Adi Satria Abadi. Jurnal Rekayasa Sistem Industri, 4(1), 47-54.

Nuruddin, A. W., Setyanto, N. W., \& Soenoko, R. (2017). Implementasi Konsep Lean Manufacturing untuk Meminimalkan Waktu Keterlambatan Penyelesaian Produk "A" sebagai Value Pelanggan: Studi Kasus Pt. Tsw (Tuban Steel Work)," Jurnal Rekayasa dan Manajemen Sistem Industri, 1 (1), 47-56.

Prayogo, T., \& Octavia, T. (2013). Identifikasi Waste dengan Menggunakan Value Stream Mapping Di Gudang PT. XYZ. Jurnal Titra. 1(2), 119-126.

Rejeki, K. S., Sinulingga, S., \& Tarigan, U. (2013). Evaluasi dan Analisis Produktivitas dengan Menggunakan Metode Marvin E. Mundel Di PT. XYZ, Jurnal Teknik Industri FT USU, 2(1), 48-53.

Ristyowati, T., \& Muhsin, A. (2017). Minimasi Waste pada Aktivitas Proses Produksi dengan Konsep Lean Manufacturing. Jurnal Optimasi Sistem Industri, 10(1), 85-96. 
DOI: https://doi.org/10.26593/jrsi.v10i1.3813.89-100

Halaman ini sengaja dikosongkan.

This page is intentionally left blank. 